\title{
Pengaruh Pemberian Sumber Silikon pada Sifat Kimia dan Pertumbuhan Tanaman Padi pada Tiga Jenis Tanah
}

\section{(The Effect of Silicon Source on Soil Chemical Properties and Rice Growth on Three Soil Types)}

\author{
Mirawanty Amin*, Hartin Kasim, Faisal \\ (Diterima Januari 2020/Disetujui Agustus 2021)
}

\begin{abstract}
ABSTRAK
Silikon (Si) memiliki peran penting dalam pertumbuhan tanaman padi dan beberapa sifat kimia tanah. Akan tetapi, Si masih kurang mendapat perhatian karena informasi yang tersedia mengenai manfaat Si pada tanaman padi masih sangat kurang dan belum banyak penelitian yang dilakukan tentang peranan Si pada tanaman padi. Hal tersebut menyebabkan dalam praktik di lapangan, tidak dilakukan penambahan $\mathrm{Si}$ yang akhirnya menyebabkan proses desilikasi tanah, yaitu pemindahan atau keluarnya silika dari solum tanah. Salah satu sumber Si yang dapat digunakan sebagai pupuk adalah tras. Pada saat ini, tras lebih banyak digunakan oleh masyarakat sebagai bahan dasar pembuatan batako. Akan tetapi, penggunaan tras sebagai sumber Si belum banyak diketahui. Oleh karena itu, perlu dilakukan penelitian tentang pengaruh tras pada pertumbuhan tanaman padi dan sifat kimia tanah. Tujuan penelitian ini adalah menganalisis efek pemberian tras pada sifat kimia tanah dan pertumbuhan padi. Rancangan percobaan yang digunakan adalah split plot dengan tiga jenis tanah, yaitu oxisol, inceptisol, dan vertisol sebagai petak utama dan tujuh dosis tras, yaitu 0 (D0); 1,25 (D1); 2,5 (D2); 3,75 (D3); 5 (D4); 7,5 (D5); 10 (D6) $\mathrm{g} \mathrm{kg}^{-1}$ tanah sebagai anak petak. Perlakuan merupakan kombinasi dari kedua faktor tersebut dan diulang 3 kali sehingga diperoleh 63 unit percobaan. Hasil penelitian menunjukkan bahwa pemberian tras berpengaruh nyata pada peningkatan pH, $\mathrm{P}-$ tersedia, Ca-dd, Mg-dd, serta berpengaruh nyata menurunkan Fe dan Mn tersedia. Sementara itu, pemberian tras juga memberikan pengaruh nyata pada tinggi tanaman, yaitu $91 \mathrm{~cm}$ dan jumlah anakan, yaitu 21 batang.
\end{abstract}

Kata kunci: padi, sifat kimia, silicon, tras

\section{ABSTRACT}

Silicon (Si) has an important role in the growth of rice plants and some soil chemical properties. However, Si still receives less attention, because there is still little information about the importance of Si for rice plants and not many researches have been done on the use of $\mathrm{Si}$ in rice plants. This condition causes the farmers do not practice the use of $\mathrm{Si}$ as a fertilizer that eventually removal or release of silica from the soil solum. One source of $\mathrm{Si}$ that can be used as a fertilizer is trass. Currently, the trass has been widely used by the community as the basic material for making bricks. However, the use of trass as a source of $\mathrm{Si}$ in agriculture is not widely known. Therefore, it is necessary to evaluate the effect of trass on rice plant growth and soil chemical properties. The purpose of this study was to analyze the effect of trass addition on soil chemical properties and rice growth. The experimental design used was a separate plot where three types of soil, namely oxisol, inceptisol, and vertisol as the main plot and seven doses of trass were 0 (D0); 1.25 (D1); 2.5 (D2); 3.75 (D3); 5 (D4); 7.5 (D5); and 10 (D6) g kg-1 of soil as sub-plots. The treatment was a combination of these two factors and was repeated 3 times to obtain 63 experimental units. The results showed that the administration of trass significantly increased $\mathrm{pH}$, available $\mathrm{P}, \mathrm{Ca}-\mathrm{dd}, \mathrm{Mg}$-dd, and significantly decreased available $\mathrm{Fe}$ and $\mathrm{Mn}$. Meanwhile, the provision of trass also significantly affected plant height, namely $91 \mathrm{~cm}$, and the number of tillers, namely 21 stems.

Key words: chemical properties, rice, silicon, trass

\section{PENDAHULUAN}

Silikon (Si) merupakan unsur kedua terbanyak di kerak bumi (sekitar 28\%), setelah oksigen, tetapi tidak dianggap penting untuk pertumbuhan tanaman (Eipstein 1999). Meskipun keberadaan Si di dalam

Balai Pengkajian Teknologi Pertanian (BPTP) Sulaweis Utara, Jl. Kampus Pertanian Kalasey, Manado, Sulawesi Utara, 95013

* Penulis Korespondensi:

Email: mirawantyamin@gmail.com tanah melimpah, sebagian besar $\mathrm{Si}$ terdapat dalam bentuk silika $\left(\mathrm{SiO}_{2}\right)$ yang tidak dapat diserap oleh tanaman. Meskipun Si masih belum dianggap sebagai unsur hara essensial, beberapa hasil penelitian menunjukkan bahwa Si meningkatkan hasil dan pertumbuhan tanaman, seperti padi (Anggria et al. 2020).

Silikon memiliki peran dalam beberapa sifat kimia tanah. Pemberian pupuk Si melalui tanah menyebabkan penurunan fiksasi $\mathrm{P}$ dan peningkatan serapan $\mathrm{P}$ oleh tanaman (Lima 2011). Selain itu, pemberian Si juga mengurangi toksisitas logam (Raven1983; Rogalla 2002), meningkatkan aktivitas enzim (Datnoff 
et al. 2001), meningkatkan pertumbuhan, memperkuat batang, meningkatkan jumlah malai, menjaga agar daun tetap tegak agar proses fotosintesis dapat berjalan dengan baik (Husnain 2011; Rao et al. 2017), dan meningkat-kan ketahanan tanaman terhadap hama dan penyakit (Zellner et al. 2011; Van Bockhaven et al. 2013; Liang et al. 2015; Sakr et al. 2016). Berdasarkan peran-peran tersebut, silikon dikenal sebagai beneficial element (Broadley et al. 2012).

Silikon dikenal sebagai unsur yang menguntungkan bagi tanaman padi. Akan tetapi, masih sedikit informasi yang tersedia mengenai manfaat $\mathrm{Si}$ untuk tanaman padi dan masih banyak yang belum melakukan penelitian silikon. Pada kenyataannya di lapangan, petani pada umumnya hanya memperhatikan penggunaan pupuk hara makro saja sehingga tidak ada penambahan Si dalam praktik bercocok tanam yang menyebabkan terjadinya proses desilikasi atau pengurasan kandungan Si tanah. Hal tesebut menyebabkan perlunya penambahan pupuk atau sumber silika (Meena et al. 2014; Marxen et al. 2016).

Penambahan pupuk atau sumber Si merupakan salah satu cara yang dapat dilakukan untuk meningkatkan pertumbuhan padi. Sebagai contoh, dengan perhitungan panen gabah 4,5 ton ha ${ }^{-1}$ dan jerami 5 ton per hektar dalam sekali panen, dan sekam meliputi 30\% bobot gabah, maka dalam sekali panen di sawah dusun Lembur Leutik (belakang kampus IPB Darmaga) akan terangkut $971 \mathrm{~kg} \mathrm{SiO}_{2} \mathrm{ha}^{-1}$. Kadar $\mathrm{SiO}_{2}$ sekam dan jerami padi di daerah tersebut adalah 21,23 dan $16,01 \%$ (Nugroho 2009).

Salah satu cara yang dapat dilakukan agar $\mathrm{Si}$ di dalam tanah tidak mengalami penurunan secara terus menerus adalah dilakukan pemberian pupuk Si. Salah satu sumber pupuk Si yang dapat digunakan adalah tras (Amin et al. 2019). Tras merupakan salah satu bahan alam yang mengandung 50,13\% $\mathrm{SiO}_{2}$ (Van Bemmelen 1997) sehingga berpotensi untuk dimanfaatkan sebagai pupuk Si. Tras terbentuk dari abu vulkanik yang memiliki kandungan unsur kalsium dan silika (Utomo 2011). Tras banyak digunakan sebagai bahan untuk pembuatan batako. Akan tetapi, pada saat ini, belum banyak yang mengetahui bahwa tras dapat dijadikan sebagai sumber Si.

Tujuan penelitian ini diharapkan bahwa tras dapat berpengaruh pada sifat kimia tanah, seperti meningkatkan $\mathrm{pH} \mathrm{H}_{2} \mathrm{O}, \mathrm{Ca}$-dd, Mg-dd, P-tersedia, pertumbuhan tanaman, dan menurunkan $\mathrm{Fe}$ dan $\mathrm{Mn}$ yang tersedia pada tanah.

\section{METODE PENELITIAN}

\section{Tempat dan Waktu Penelitian}

Percobaan dilakukan di Laboratorium Kimia dan Kesuburan Tanah dan Rumah Kaca Kebun Percobaan Cikabayan, Departemen IImu Tanah dan Sumberdaya Lahan, Fakultas Pertanian, Institut Pertanian Bogor. Penelitian berlangsung dari bulan Januari sampai September 2017.

\section{Bahan dan Alat}

Bahan tanah yang digunakan dalam penelitian ini meliputi tiga jenis tanah sawah yang tergolong oxisol dari Gunung Sindur dengan kandungan $\mathrm{SiO}_{2} 47,76 \mathrm{mg}$ $\mathrm{kg}^{-1}$ (rendah), inceptisol dari Ciampea Bogor dengan kandungan $\mathrm{SiO}_{2} 104,86 \mathrm{mg} \mathrm{kg}^{-1}$ (sedang), dan vertisol dari Cihea, Cianjur dengan kandungan $\mathrm{SiO}_{2} 159,84 \mathrm{mg}$ $\mathrm{kg}^{-1}$ (tinggi) (Amin et al. 2019). Bahan tras yang berasal dari Ciampea, Bogor yang dikombinasikan dengan $\mathrm{CaCO}_{3}$ digunakan sebagai sumber pupuk silika. Pupuk dasar dalam penelitian ini meliputi urea, SP36, dan $\mathrm{KCl}$. Bahan lain yang digunakan adalah bahan kimia yang digunakan untuk analisis di laboratorium.

Alat yang digunakan dalam penelitian ini meliputi kertas label, plastik, kamera, gelas plastik, saringan, dan beberapa alat untuk analisis di laboratorium.

\section{Prosedur Penelitian}

\section{- Analisis Tanah Awal}

Analisis awal dilakukan pada tiga jenis tanah, yaitu oxisol, inceptisol, dan vertisol (Tabel 1).

Tabel 1 Hasil analisis awal tanah oxisol, inceptisol, dan vertisol

\begin{tabular}{|c|c|c|c|c|c|}
\hline Sifat tanah & Satuan & Metode & Oxisol & Inceptisol & Vertisol \\
\hline $\mathrm{pH} \mathrm{H}_{2} \mathrm{O}$ & - & $\mathrm{pH}$ Meter & 5,35 & 5,4 & 5,04 \\
\hline $\mathrm{P}_{2} \mathrm{O}_{5}$ & Ppm & Bray 1 & 15,44 & 1,17 & 14,82 \\
\hline Si Tersedia & Ppm & $\mathrm{NH}_{4} \mathrm{OAc} \mathrm{pH} 4.8$ & 22,32 & 49 & 74,69 \\
\hline KTK & $\mathrm{cmol}(+) \mathrm{kg}^{-1}$ & N NH4OAc pH 7.0 & 17,48 & 25,06 & 47,55 \\
\hline Ca-dd & $\mathrm{cmol}(+) \mathrm{kg}^{-1}$ & N NH4OAc pH 7.0 & 4,05 & 8,99 & 13,25 \\
\hline Mg-dd & $\mathrm{cmol}(+) \mathrm{kg}^{-1}$ & N NH4OAc pH 7.0 & 0,92 & 2,51 & 1,35 \\
\hline K-dd & $\mathrm{cmol}(+) \mathrm{kg}^{-1}$ & N NH4OAc pH 7.0 & 0,35 & 0,92 & 1,34 \\
\hline Na-dd & $\mathrm{cmol}(+) \mathrm{kg}^{-1}$ & N NH4OAc pH 7.0 & 0,56 & 0,71 & 1,02 \\
\hline C-Organik & $\%$ & Walkley \& Black & 2,96 & 1,51 & 1,96 \\
\hline $\mathrm{N}$-Total & $\%$ & Kjehdahl & 0,21 & 0,16 & 0,24 \\
\hline Al-dd & $\operatorname{cmol}(+) \mathrm{kg}^{-1}$ & $\mathrm{~N} \mathrm{KCl}$ & 0,56 & nd & nd \\
\hline H-dd & $\mathrm{cmol}(+) \mathrm{kg}^{-1}$ & $\mathrm{~N} \mathrm{KCl}$ & nd & 0,11 & 0,11 \\
\hline $\mathrm{Fe}$ & ppm & DTPA & nd & 23,42 & 177,12 \\
\hline $\mathrm{Cu}$ & $\mathrm{ppm}$ & DTPA & nd & 2,13 & 9,09 \\
\hline $\mathrm{Zn}$ & ppm & DTPA & nd & 3,42 & 7,14 \\
\hline $\mathrm{Mn}$ & ppm & DTPA & nd & 61,15 & 93,70 \\
\hline
\end{tabular}

$\mathrm{nd}=$ tidak ditetapkan 


\section{- Pemilihan Pupuk Silikon Terbaik}

Pada tahap awal, telah dilakukan penelitian mengenai penentuan formula pupuk silikon yang berasal dari tras bakar dan tanpa pembakaran. Proses pembakaran diawali dengan penimbangan tras lolos saringan 100 mesh dan penambahan $\mathrm{CaCO}_{3}$ teknis, dengan perbandingan $100 \%$ tras: $0 \% \mathrm{CaCO}_{3}, 83,33 \%$ tras: $16,67 \% \mathrm{CaCO}_{3}$, dan $66,67 \%$ tras:33,33\% $\mathrm{CaCO}_{3}$. Untuk pupuk $\mathrm{Si}$ yang dibakar, satu set campuran tersebut selanjutnya dipanaskan dalam tanur pada suhu $700^{\circ} \mathrm{C}$ selama 2 jam. Campuran tras yang dipanaskan selanjutnya didinginkan dan ditambahkan aquades sebanyak $330 \mathrm{~mL}$. Setelah itu, dipanaskan kembali pada suhu $500^{\circ} \mathrm{C}$ selama satu jam. Satu set campuran lainnya tidak mendapatkan perlakuan pemanasan. Hasil menunjukkan bahwa perlakuan $83,33 \%$ tras yang dikombinasikan dengan $16,67 \%$ $\mathrm{CaCO}_{3}$ melalui proses pemanasan memberikan nilai $\mathrm{Si}$ tersedia tertinggi $\left(156,12 \mathrm{mg} \mathrm{SiO} \mathrm{kg}^{-1} \mathrm{HCl} 0,5 \mathrm{M}\right)$, sehingga untuk percobaan laboratorium dan rumah kaca menggunakan pupuk Si tersebut (Amin et al. 2019).

\section{- Desain Penelitian}

Percobaan inkubasi tanah di laboratorium dan percobaan rumah kaca menggunakan rancangan acak lengkap faktorial dengan faktor pertama adalah tiga jenis tanah, yaitu oxisol $\left(S_{1}\right)$, inceptisol $\left(S_{2}\right)$, dan vertisol $\left(S_{3}\right)$. Faktor kedua adalah tujuh dosis perlakuan tras bakar, yaitu kontrol $0 \mathrm{~g} \mathrm{~kg}^{-1}\left(\mathrm{D}_{0}\right) ; 1,25 \mathrm{~g} \mathrm{~kg}^{-1}\left(\mathrm{D}_{1}\right)$; $2,5 \mathrm{~g} \mathrm{~kg}^{-1}\left(\mathrm{D}_{2}\right) ; 3,75 \mathrm{~g} \mathrm{~kg}^{-1}\left(\mathrm{D}_{3}\right) ; 5 \mathrm{~g} \mathrm{~kg}^{-1}\left(\mathrm{D}_{4}\right) ; 7,5 \mathrm{~g} \mathrm{~kg}^{-1}$ $\left(D_{5}\right)$; dan $10 \mathrm{~g} \mathrm{~kg}^{-1}\left(\mathrm{D}_{6}\right)$. Percobaan diulang sebanyak tiga kali sehingga diperoleh 63 satuan percobaan.

\section{- Percobaan Inkubasi Tanah di Laboratorium}

Sebanyak $200 \mathrm{~g}$ bobot kering mutlak (BKM) tanah dari ketiga jenis tanah tersebut ditambahkan tras sesuai dengan perlakuan dan diinkubasi selama satu bulan. Setelah inkubasi berakhir dilakukan analisis sifat kimia $\mathrm{pH} \mathrm{H}_{2} \mathrm{O}$, P-tersedia, $\mathrm{Ca}$-dd, $\mathrm{Mg}$-dd, serta Fe dan Mn tersedia (Tabel 2).

\section{- Percobaan Rumah Kaca}

Bahan tanah dari lapang pertama-tama dikeringudarakan sambil dihaluskan hingga lolos saringan 5 $\mathrm{mm}$. Selanjutnya, tanah ditimbang setara $5 \mathrm{~kg}$ BKM dan dimasukkan ke dalam ember. Kemudian masingmasing perlakuan pupuk $\mathrm{Si}$ terpilih dimasukkan ke dalam ember dan diaduk hingga rata dengan tanah. Selanjutnya diinkubasi selama satu minggu pada kondisi tergenang $\pm 5 \mathrm{~cm}$. Setelah masa inkubasi berakhir dilakukan penanaman bibit padi.

Sebanyak 3 bibit padi varietas Ciherang umur 20 hari ditanam di setiap pot. Pupuk dasar yang meliputi
Urea, SP-36, dan $\mathrm{KCl}$, diberikan sesuai dengan dosis rekomendasi, yaitu $0,6 \mathrm{~g}$ urea kg-1, 0,2 g SP-36 kg-1, dan $0,2 \mathrm{~g} \mathrm{KCl} \mathrm{kg}^{-1}$. Urea dan $\mathrm{KCl}$ diberikan sebanyak tiga kali, yaitu pada saat tanam, 2 minggu setelah tanam (MST), dan pada saat vegetatif maksimum (10 MST). Sementara itu, SP-36 diberikan satu kali pada saat penanaman. Kondisi air tergenang $\pm 5 \mathrm{~cm}$ dipertahankan selama percobaan berlangsung. Jika ditemukan gulma, penyiangan dilakukan secara manual dengan cara mencabut gulma. Pengendalian hama dilakukan seperlunya dengan insektisida bahan aktif beta siflurin. Pada saat 10 MST dilakukan pengukuran untuk menghitung jumlah anakan dan tinggi tanaman.

\section{Analisis Data}

Analisis data percobaan dilakukan dengan splitplot. Pengujian signifikansi untuk mengetahui pengaruh perlakuan digunakan uji Fisher. Apabila uji $\mathrm{F}$ signifikan maka untuk melihat rata-rata perbedaan dilakukan uji Duncan Multiple Range Test (DMRT) pada dosis nyata $5 \%$.

\section{HASIL DAN PEMBAHASAN}

\section{Pengaruh Tras pada Sifat Kimia Tanah}

Pengamatan pengaruh tras pada sifat kimia tanah dilakukan dengan percobaan inkubasi dengan menggunakan tras terpilih $\left(83,33 \%\right.$ tras $\left.+16,67 \% \mathrm{CaCO}_{3}\right)$. Hasil sidik ragam menunjukkan bahwa perlakuan tras berpengaruh nyata meningkatkan $\mathrm{pH} \mathrm{H}_{2} \mathrm{O}, \mathrm{Ca}-\mathrm{dd}$, Mg$\mathrm{dd}$, dan P-tersedia serta berpengaruh sangat nyata menurunkan Fe dan Mn tersedia. Hasil uji Duncan pengaruh tras pada variabel tersebut disajikan pada Tabel 3.

Hasil uji Duncan tersebut menunjukkan bahwa $D_{6}$ memberikan nilai $\mathrm{pH} \mathrm{H}_{2} \mathrm{O}$ tertinggi pada ketiga jenis tanah, yaitu 5,98 pada oxisol, 6,30 pada inceptisol, dan 6,71 pada vertisol (Tabel 3). Haynes et al. (2013) menyatakan bahwa pemberian pupuk silikon dapat meningkatkan $\mathrm{pH}$ tanah. Menurut Berthelsen et al. (2003), peningkatan pH terjadi karena pemberian pupuk silikon yang bersifat slow released akan larut perlahan dan menghasilkan gugus $\mathrm{OH}^{-}$.

Summer dan Ferina (1986) mengemukakan bahwa reaksi silikat di dalam tanah sama seperti yang terjadi pada proses pengapuran, yaitu dapat meningkatkan $\mathrm{pH}$ tanah. Reaksi netralisasi asam oleh $\mathrm{CaSiO}_{3}$ dan $\mathrm{CaCO}_{3}$ serupa membentuk asam lemah terlarut. Savant et al. (1999) menyatakan bahwa efek penetralan yang dihasilkan oleh silikat pada keasaman tanah terjadi melalui reaksi anion $\mathrm{SiO}_{3}{ }^{2-}$ dengan proton $\mathrm{H}^{+}$dalam larutan tanah. Reaksi $\mathrm{CaSiO}_{3}$ dengan $\mathrm{H}_{2} \mathrm{O}$ menghasilkan asam lemah $\mathrm{H}_{4} \mathrm{SiO}_{4}$ (Alves et al. 2016).

Tabel 2 Analisis dan metode analisis sifat kimia tanah

\begin{tabular}{|c|c|c|c|}
\hline Analisis & Ekstraktan & Satuan & Metode, alat ukur \\
\hline $\mathrm{pH} \mathrm{H} \mathrm{H}_{2} \mathrm{O}$ & $\mathrm{H}_{2} \mathrm{O}$ & - & Elektroda (pH meter) \\
\hline P-tersedia & Bray I & ppm & Spectrophotometer \\
\hline Ca-dd dan Mg-dd & $\mathrm{NH}_{4} \mathrm{OAc} 1 \mathrm{~N} \mathrm{pH} \mathrm{7,0}$ & $\mathrm{cmol}(+) \mathrm{kg}^{-1}$ & Atomic Absorption Spectrophotometer (AAS) \\
\hline Fe dan Mn tersedia & DTPA & ppm & Atomic Absorption Spectrophotometer (AAS) \\
\hline
\end{tabular}


Selain itu, keberadaan $\mathrm{H}_{4} \mathrm{SiO}_{4}$ sebagai asam lemah menyebabkan $\mathrm{H}^{+}$terdesosiasi lemah sehingga $\mathrm{Ca}^{2+}$ menjadi tersedia, $\mathrm{OH}^{-}$menetralkan $\mathrm{H}^{+}$, dan $\mathrm{pH}$ tanah akan meningkat. Oleh karena itu, peningkatan kelarutan $\mathrm{Si}$ pada tras berpengaruh meningkatkan $\mathrm{pH}$. Dengan peningkatan $\mathrm{pH}$, maka Si tersedia tanah juga meningkat. Szulc et al. (2015) menyatakan bahwa ketersediaan $\mathrm{H}_{4} \mathrm{SiO}_{4}$ di tanah bergantung pada $\mathrm{pH}$ tanah serta kandungan $\mathrm{Al}$ dan $\mathrm{Fe}$ di dalam tanah. Tanah dengan $\mathrm{pH}$ tinggi akan meningkatkan konsentrasi $\mathrm{H}_{4} \mathrm{SiO}_{4}$ di dalam tanah, tetapi peningkatan konsentrasi $\mathrm{H}_{4} \mathrm{SiO}_{4}$ yang terus menerus dapat meningkatkan adsorpsi, terutama di tanah yang memiliki kandungan tanah liat yang tinggi (Paye 2016). Meskipun pupuk Si memiliki reaksi yang sama seperti proses pengapuran, potensi pengapurannya bergantung pada ukuran partikel, praktik manajemen, lamanya kontak dengan tanah, dan iklim di daerah tersebut (Alcarde \& Rodella 2003).

Hasil sidik ragam menunjukkan bahwa pemberian tras berpengaruh nyata pada Ca-dd dan Mg-dd. Nilai Ca-dd pada analisis tanah awal pada oxisol, inceptisol, dan vertisol (Tabel 1) adalah 4,05 $\mathrm{cmol}(+) \mathrm{kg}^{-1}, 8,99$ cmol(+) $\mathrm{kg}^{-1}$, dan $13,25 \mathrm{cmol}(+) \mathrm{kg}^{-1}$. Nilai Mg-dd pada analisis awal untuk oxisol, inceptisol, dan vertisol adalah $0,92 \mathrm{cmol}(+) \mathrm{kg}^{-1}, 2,51 \mathrm{cmol}(+) \mathrm{kg}^{-1}$, dan 1,35 $\mathrm{cmol}(+) \mathrm{kg}^{-1}$. Hasil inkubasi yang dilakukan di laboratorium menunjukkan bahwa nilai Ca-dd dan $\mathrm{Mg}$ dd pada tiga jenis tanah yang digunakan mengalami peningkatan dibandingkan dengan hasil analisis tanah awal. Hasil uji Duncan menunjukkan bahwa $D_{6}$ memberikan Ca-dd tertinggi untuk ketiga jenis tanah, yaitu oxisol 21,11, inceptisol 12,62, dan vertisol 56,37 $\mathrm{cmol}(+) \mathrm{kg}^{-1}$. D5 memberikan nilai $\mathrm{Mg}$-dd tertinggi untuk oxisol dan inceptisol, yaitu 5,73 dan $4,37 \mathrm{cmol}(+) \mathrm{kg}^{-1}$, sedangkan $\mathrm{D}_{6}$ memberikan Mg-dd tertinggi pada vertisol, yaitu $13,02 \mathrm{cmol}(+) \mathrm{kg}^{-1}$ (Tabel 3). Secara keseluruhan dapat dilihat bahwa peningkatan dosis tras meningkatkan pula Ca-dd dan Mg-dd. Hal tersebut terjadi karena tras mengandung $\mathrm{Ca} 1,61 \%$ dan $\mathrm{Mg}$ 28,80 ppm (Hadi 2013). Berthelsen et al. (2003) menyatakan bahwa pemberian Ca-silikat meningkatkan Ca-dd bergantung pada jumlah Ca-silikat yang diberikan.

Berdasarkan penelitian ini, peningkatan dosis tras dapat meningkatkan $P$ tersedia (Tabel 2). Perlakuan tras dengan dosis $10 \mathrm{~g} \mathrm{~kg}^{-1}\left(D_{6}\right)$ memberikan kadar $P$ tersedia tertinggi untuk jenis tanah inceptisol dan vertisol. Kadar Si yang tinggi dalam larutan tanah meningkatkan pelepasan fosfor yang terikat secara elektrostatis dalam tanah. Dengan timbulnya muatan negatif pada reaksi antara senyawa $\mathrm{Si}$ dengan sesquioksida di dalam tanah menimbulkan daya tolak terhadap fosfat hingga tidak terikat di kompleks pertukaran (Pulz et al. 2008; Nugroho 2009; Haynes 2014) sehingga melepaskan $P$ ke dalam larutan tanah dan meningkatkan ketersediaan P di dalam tanah.

Hasil uji Duncan menunjukkan bahwa perlakuan dengan dosis $5 \mathrm{~g} \mathrm{~kg}^{-1}$ tanah $\left(D_{4}\right), 10 \mathrm{~g} \mathrm{~kg}^{-1}$ tanah $\left(D_{6}\right)$, dan $7.5 \mathrm{~g} \mathrm{~kg}^{-1}$ tanah (D5) memberikan nilai terendah untuk Fe dan Mn tersedia pada oxisol, inceptisol, dan vertisol (Tabel 3). Pada analisis awal Fe dan Mn pada inceptisol adalah 23,42 dan $61,16 \mathrm{mg} \mathrm{kg}^{-1}$, sedangkan pada vertisol adalah 177,12 dan $93,70 \mathrm{mg} \mathrm{kg}^{-1}$. Pada tanah dalam kondisi tergenang, tanaman akan lebih menyukai menyerap Fe dalam bentuk fero dibandingkan feri (Tubaña \& Heckman 2015). Wallace (1993) menyatakan bahwa pentingnya pemberian pupuk $\mathrm{Si}$ agar dapat meningkatkan pelepasan $\mathrm{OH}^{-}$dan $\mathrm{pH}$ tanah sehingga kelarutan $\mathrm{Fe}$ menurun. Hal tersebut dapat

Tabel 3 Hasil analisis sifat kimia tanah pada pH H2O, Ca-dd, Mg-dd, P, Fe, dan Mn tersedia

\begin{tabular}{|c|c|c|c|c|c|c|}
\hline \multirow{2}{*}{ Perlakuan } & \multirow{2}{*}{$\mathrm{pH} \mathrm{H} \mathrm{H}_{2} \mathrm{O}$} & Ca-dd & Mg-dd & P-tersedia & Fe tersedia & Mn tersedia \\
\hline & & \multicolumn{2}{|c|}{$\ldots \ldots \mathrm{cmol}(+) \mathrm{kg}^{-} \ldots \ldots$} & & $\ldots . \mathrm{mg} \mathrm{kg}^{-1} .$. & \\
\hline $\mathrm{S}_{1} \mathrm{D}_{0}$ & $5,50 \mathrm{c}$ & $13,89 \mathrm{~F}$ & $4,68 \mathrm{~h}$ & $15,44 \mathrm{a}$ & $191,53 \mathrm{t}$ & $82,65 q$ \\
\hline $\mathrm{S}_{1} \mathrm{D}_{1}$ & $5,67 d$ & $14,44 G$ & $5,34 k$ & $18,04 \mathrm{~b}$ & $190,52 \mathrm{~s}$ & $82,75 r$ \\
\hline $\mathrm{S}_{1} \mathrm{D}_{2}$ & $5,74 \mathrm{de}$ & 17,681 & $5,35 \mathrm{k}$ & $26,93 \mathrm{~d}$ & $161,08 \mathrm{~m}$ & $66,21 n$ \\
\hline $\mathrm{S}_{1} \mathrm{D}_{3}$ & $5,79 e$ & $14,97 \mathrm{H}$ & 5,531 & 30,28 ef & 170,590 & $60,20 \mathrm{k}$ \\
\hline $\mathrm{S}_{1} \mathrm{D}_{4}$ & $5,69 d$ & $20,87 \mathrm{~K}$ & $5,30 \mathrm{j}$ & $35,56 \mathrm{ij}$ & $115,92 \mathrm{~h}$ & 59,18 j \\
\hline $\mathrm{S}_{1} \mathrm{D}_{5}$ & $5,49 c$ & 18,73J & $5,73 \mathrm{~m}$ & $30,03 \mathrm{e}$ & 142,03 I & $61,44 \mid$ \\
\hline $\mathrm{S}_{1} \mathrm{D}_{6}$ & $5,98 f$ & $21,11 \mathrm{~L}$ & $5,00 \mathrm{i}$ & $33,46 \mathrm{gh}$ & $232,01 \mathrm{u}$ & 72,040 \\
\hline $\mathrm{S}_{2} \mathrm{D}_{0}$ & $5,15 a$ & $8,74 B$ & $2,64 d$ & $29,27 \mathrm{e}$ & $25,44 f$ & $105,54 \mathrm{t}$ \\
\hline $\mathrm{S}_{2} \mathrm{D}_{1}$ & $5,34 b$ & $8,15 \mathrm{~A}$ & $1,51 \mathrm{a}$ & $25,84 d$ & $18,20 \mathrm{c}$ & $65,97 \mathrm{~m}$ \\
\hline $\mathrm{S}_{2} \mathrm{D}_{2}$ & $5,19 a$ & $8,24 \mathrm{~A}$ & $3,29 \mathrm{e}$ & $18,04 \mathrm{~b}$ & $22,49 \mathrm{e}$ & $72,82 p$ \\
\hline $\mathrm{S}_{2} \mathrm{D}_{3}$ & $5,31 b$ & $9,08 C$ & $3,50 f$ & 29,36 e & $21,37 d$ & $97,45 \mathrm{~s}$ \\
\hline $\mathrm{S}_{2} \mathrm{D}_{4}$ & $5,30 b$ & $10,48 D$ & $2,30 \mathrm{c}$ & $18,55 b$ & $9,33 b$ & $40,19 h$ \\
\hline $\mathrm{S}_{2} \mathrm{D}_{5}$ & $6,16 \mathrm{~g}$ & $10,43 \mathrm{D}$ & $4,37 \mathrm{~g}$ & $23,74 c$ & $27,21 \mathrm{~g}$ & $46,83 i$ \\
\hline $\mathrm{S}_{2} \mathrm{D}_{6}$ & $6,30 \mathrm{~h}$ & $12,62 \mathrm{E}$ & $2,12 b$ & $32,04 \mathrm{fg}$ & $8,29 a$ & $16,84 \mathrm{a}$ \\
\hline $\mathrm{S}_{3} \mathrm{D}_{0}$ & $6,15 \mathrm{~g}$ & $37,89 \mathrm{M}$ & $11,37 n$ & $33,04 \mathrm{gh}$ & $162,20 n$ & $32,40 \mathrm{e}$ \\
\hline$S_{3} D_{1}$ & $6,46 i$ & $51,69 Q$ & $18,81 \mathrm{~s}$ & $34,72 \mathrm{hi}$ & $174,98 p$ & $38,94 \mathrm{~d}$ \\
\hline $\mathrm{S}_{3} \mathrm{D}_{2}$ & $6,50 \mathrm{ij}$ & 49,140 & $17,84 r$ & $37,23 \mathrm{j}$ & $185,69 r$ & $33,31 \mathrm{f}$ \\
\hline $\mathrm{S}_{3} \mathrm{D}_{3}$ & $6,35 \mathrm{~h}$ & $40,70 \mathrm{~N}$ & $15,71 q$ & $42,68 \mathrm{k}$ & $130,24 j$ & $33,56 \mathrm{~g}$ \\
\hline $\mathrm{S}_{3} \mathrm{D}_{4}$ & $6,35 \mathrm{~h}$ & $56,66 \mathrm{~S}$ & $22,03 t$ & $41,59 \mathrm{k}$ & $182,88 q$ & $32,32 \mathrm{e}$ \\
\hline $\mathrm{S}_{3} \mathrm{D}_{5}$ & $6,58 \mathrm{j}$ & $50,05 \mathrm{P}$ & 11,650 & 48,801 & $119,77 i$ & $20,53 \mathrm{~b}$ \\
\hline $\mathrm{S}_{3} \mathrm{D}_{6}$ & $6,71 \mathrm{k}$ & $56,37 \mathrm{R}$ & $13,02 p$ & $57,18 \mathrm{~m}$ & $141,41 \mathrm{k}$ & $23,41 \mathrm{c}$ \\
\hline
\end{tabular}

Keterangan: Angka yang diikuti oleh huruf yang sama pada kolom yang sama menunjukkan tidak berbeda nyata pada dosis nyata $5 \% . S_{1}=$ oxisol; $S_{2}=$ inceptisol; $S_{3}=$ vertisol; $D_{0}=$ kontrol; $D_{1}=1,25 ; D_{2}=2,5 ; D_{3}=3,75 ; D_{4}=5 ; D_{5}=7,5 ;$ $\mathrm{D}_{6}=10 \mathrm{~g} \mathrm{~kg}^{-1}$ 
dikonfirmasi pada penelitian ini bahwa pemberian tras menurunkan Fe tersedia menjadi $8,29 \mathrm{mg} \mathrm{kg}^{-1}$ pada inceptisol, $119.77 \mathrm{mg} \mathrm{kg}^{-1}$ pada vertisol, sedangkan $\mathrm{Mn}$ tersedia menurun menjadi $16.84 \mathrm{mg} \mathrm{kg}^{-1}$ pada inceptisol dan $20.53 \mathrm{mg} \mathrm{kg}^{-1}$ pada vertisol.

\section{Pengaruh Tras pada Pertumbuhan Padi}

Hasil analisis ragam menunjukkan bahwa jenis tanah secara tunggal berpengaruh nyata pada tinggi tanaman dan jumlah anakan maksimum pada $10 \mathrm{MST}$, sedangkan perlakuan tras dan kombinasi antara jenis tanah dan tras tidak berpengaruh nyata. Hasil uji Duncan menunjukkan bahwa jenis tanah berpengaruh pada tinggi tanaman 10 MST (Tabel 4), yaitu bahwa tinggi tanaman yang ditanam pada tanah vertisol $\left(\mathrm{S}_{3}\right)$ lebih tinggi dibandingkan dengan yang ditanam di tanah oxisol $\left(\mathrm{S}_{1}\right)$ dan inceptisol $\left(\mathrm{S}_{2}\right)$. Jenis tanah inceptisol $\left(S_{2}\right)$ memiliki nilai Si tersedia yang tergolong sedang, tetapi pada penelitian ini memberikan nilai tinggi tanaman terendah. Hal tersebut diduga terkait dengan keberadaan logam Mn. Logam Mn pada jenis tanah inceptisol memiliki nilai yang lebih tinggi dibandingkan dengan jenis tanah oxisol dan vertisol (Tabel 3). Adanya logam Mn yang tinggi di tanah akan menghambat pertumbuhan tanaman (Arif et al. 2016; Nawaz et al. 2021).

Jenis lahan Vertisol $\left(S_{3}\right)$ memberikan nilai tinggi tanaman yang paling tinggi dibandingkan jenis tanah yang lain. Selain sifat kimia tanah vertisol yang lebih baik, dari segi Si tersedia maupun sifat kimia lainnya, penambahan Si diduga juga meningkatkan laju fotosintesis dalam tanaman yang menyebabkan penyerapan unsur hara menjadi lebih optimal. Silika yang terakumulasi pada daun menyebabkan daun menjadi lebih tegak dan lebih terbuka sehingga permukaan daun lebih banyak mendapat sinar matahari dan proses fotosintesis menjadi lebih optimal (Putri et al. 2017; Barita 2018). Fotosintat yang dihasilkan akan digunakan untuk proses pertumbuhan, seperti peman- jangan batang (Ningsih 2012). Hasil penelitian Shuhei et al. (2009) juga mendapatkan bahwa perlakuan Si di dalam tanah dapat meningkatkan pertumbuhan vegetatif tanaman.

Dapat dilihat bahwa pemberian tras tidak berpengaruh nyata pada pertumbuhan tanaman, yaitu tinggi tanaman. Pengaruh tersebut dikarenakan kadar $\mathrm{N}$ pada analisis tanah awal memiliki kategori rendah hingga sedang. Jenis tanah oxisol memiliki kadar nitrogen $0,21 \%$ (sedang), sedangkan jenis tanah inceptisol memiliki kadar nitrogen $0,16 \%$ (rendah), sementara jenis tanah vertisol memiliki kadar nitrogen 0,24\% (sedang). Hasil tersebut dikarenakan ketersediaan nitrogen yang rendah pada tanah sehingga akan mempengaruhi pertumbuhan tanaman, salah satunya tinggi tanaman (Jafari et al. 2013; Malav et al. 2016).

Hasil uji Duncan menunjukkan pengaruh jenis tanah pada jumlah anakan umur 10 MST (Tabel 5) yang menunjukkan bahwa padi pada lahan vertisol $\left(\mathrm{S}_{3}\right)$ mempunyai rata-rata jumlah anakan tertinggi, yaitu 23 batang dan nyata lebih tinggi dibandingkan dengan padi yang ditanam di lahan oxisol $\left(S_{1}\right)$ yang juga nyata lebih tinggi dibandingkan dengan padi yang ditanam pada lahan inceptisol $\left(\mathrm{S}_{2}\right)$. Pada lahan vertisol $\left(\mathrm{S}_{3}\right)$ dan oxisol $\left(S_{1}\right)$ semua perlakuan tras cenderung meningkatkan jumlah anakan dibandingkan kontrol $\left(D_{0}\right)$.

Peningkatan ketersediaan Si akibat perlakuan tras meningkatkan serapan hara oleh akar, terutama $\mathrm{P}$, yang berperan dalam pembelahan sel sehingga dapat memacu pembentukan anakan. Hal tersebut sesuai dengan hasil penelitian Zulputra et al. (2014) yang menunjukkan bahwa jumlah anakan padi meningkat dengan peningkatan serapan $\mathrm{P}$ akibat adanya silika, karena fosfor dibutuhkan tanaman dalam proses pembelahan sel dan sebagai energi dalam setiap proses metabolisme tanaman. Hasil analisis juga menunjukkan bahwa P-tersedia meningkat dengan perlakuan pemberian tras (Tabel 2). Peningkatan serapan

Tabel 4 Pengaruh tras dan jenis tanah pada tinggi tanaman umur 10 MST

\begin{tabular}{|c|c|c|c|c|c|c|c|c|}
\hline \multirow{2}{*}{ Perlakuan } & $D_{0}$ & $\mathrm{D}_{1}$ & $D_{2}$ & $D_{3}$ & $\mathrm{D}_{4}$ & $D_{5}$ & $\mathrm{D}_{6}$ & \multirow{2}{*}{ Rata-rata } \\
\hline & \multicolumn{7}{|c|}{ 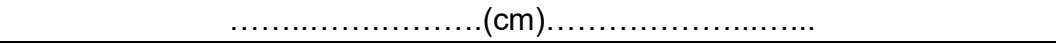 } & \\
\hline $\mathrm{S}_{1}$ (oxisol) & 85 & 85 & 81 & 80 & 81 & 81 & 85 & $82 b$ \\
\hline $\mathrm{S}_{2}$ (inceptisol) & 80 & 79 & 79 & 75 & 76 & 74 & 81 & $78 a$ \\
\hline $\mathrm{S}_{3}$ (vertisol) & 82 & 97 & 88 & 95 & 100 & 94 & 91 & $93 c$ \\
\hline Rata-rata & 82 & 87 & 83 & 83 & 85 & 83 & 86 & \\
\hline
\end{tabular}

Keterangan: Angka yang diikuti oleh huruf yang sama pada kolom yang sama menunjukkan tidak berbeda nyata pada dosis nyata $5 \% . S_{1}=$ oxisol; $S_{2}=$ inceptisol; $S_{3}=$ vertisol; $D_{0}=$ kontrol; $D_{1}=1,25 ; D_{2}=2,5 ; D_{3}=3,75 ; D_{4}=5 ; D_{5}=7,5$; $D_{6}=10 \mathrm{~g} \mathrm{~kg}^{-1}$

Tabel 5 Pengaruh tras dan jenis tanah pada jumlah anakan umur 10 MST

\begin{tabular}{|c|c|c|c|c|c|c|c|c|}
\hline \multirow{2}{*}{ Perlakuan } & $\mathrm{D}_{0}$ & $D_{1}$ & $D_{2}$ & $D_{3}$ & $\mathrm{D}_{4}$ & $D_{5}$ & $\mathrm{D}_{6}$ & \multirow{2}{*}{ Rata-rata } \\
\hline & & & & (bat & & & & \\
\hline $\mathrm{S}_{1}$ (oxisol) & 11 & 8 & 11 & 12 & 13 & 11 & 15 & $12 b$ \\
\hline $\mathrm{S}_{2}$ (inceptisol) & 11 & 10 & 13 & 8 & 10 & 10 & 12 & $10 a$ \\
\hline $\mathrm{S}_{3}$ (vertisol) & 19 & 25 & 23 & 24 & 29 & 23 & 21 & $23 c$ \\
\hline Rata-rata & 14 & 14 & 15 & 15 & 18 & 15 & 16 & \\
\hline
\end{tabular}

Keterangan: Angka yang diikuti oleh huruf yang sama pada kolom yang sama menunjukkan tidak berbeda nyata pada dosis nyata $5 \%$. $S_{1}=$ oxisol; $S_{2}=$ inceptisol; $S_{3}=$ vertisol; $D_{0}=$ kontrol; $D_{1}=1,25 ; D_{2}=2,5 ; D_{3}=3,75 ; D_{4}=5 ; D_{5}=7,5$; $D_{6}=10 \mathrm{~g} \mathrm{~kg}$ 
hara terjadi karena keberadaan Si pada tanaman dapat membuat sistem perakaran membaik sehingga akar menjadi lebih efektif dalam menyerap unsur hara (Fevi et al. 2017).

\section{KESIMPULAN}

Pemberian tras berpengaruh nyata pada peningkatan $\mathrm{pH}$, P-tersedia, Ca-dd, Mg-dd, serta berpengaruh nyata menurunkan $\mathrm{Fe}$ dan Mn tersedia. Tras tidak berpengaruh nyata pada pertumbuhan padi. Akan tetapi, jenis tanah memberikan pengaruh nyata pada pertumbuhan padi. Jenis tanah Vertisol memberikan pengaruh nyata pada pertumbuhan tanaman, yaitu tinggi tanaman dan jumlah anakan. Jenis tanah Vertisol yang memiliki kandungan Si paling tinggi dibandingkan dua jenis tanah lainnya memberikan respons terhadap pemberian tras. Dapat dilihat bahwa penambahan silikon sangat diperlukan pada tanaman padi. Tras dapat dijadikan sebagai sumber pupuk silikon.

\section{DAFTAR PUSTAKA}

Alcarde JA, Rodella AA. 2003. Quality and legislation of fertilizers and correctives. In Topics in Soil Science. 291-334.

Alves EEN, Siebeneichler EA, Costa LM, Fontes RLF, Rocha PA, Vergütz L, Hesterberg D. 2016. Polymerization of Silicic Acid Decrease Soil Liming Capacity of Silicate Minerals Applied to Soils. Raleigh (US): Departemen of Soil Science North Carolina State University

Amin M, Nugroho B, Suwarno, Tjahyandari S. 2019. Respons pemberian dan penetapan status hara $\mathrm{Si}$ pada tanaman padi. Jurnal IImu Pertanian Indonesia. 24(1): 32-40. https://doi.org/10.18343/ jipi.24.1.32

Anggria L, Husnain, Masunaga T. 2020. The controlling factors of silicon solubility in soil solution. Agric. 32(2): 83-94. https://doi.org/10.24246/agric.2020.v 32.i2.p83-94

Arif N, Yadav V, Singh S, Singh Swati, Ahamd, P, Mishra RK, Sharma S, Tripathi DK, Dubey NK, Chauhan DK. 2016. Influence of high and low levels of plant-beneficial heavy metal ions on plant growth and development. Frontiers in Environmental Science. 4(69): 1-11. https://doi.org/10.3389/fenvs .2016 .00069

Barita Y, Prihastanti E, Haryanti S, Subagio A, Ngadiwiyana. 2018. The influence of granting npk fertilizer and nanosilic fertilizers on the growth of Ganyong plant (Canna edulis Ker.). Journal of Physics: Conference Series. 1025: 1-11.

Berthelsen S, Noble AD, Kingston G, Hurney A, Rudd A, Garside A. 2003. Improving Yield and Ccs In Sugarcane Through The Application Of Silicon
Based Amendements. Thailand (TH): Sugar research and development corporation.

Broadley M, Brown P, Cakmak I, Ma JF, Rengel Z, Zhao F. 2012. Beneficial Elements. In Marschner's Mineral Nutrition of Higher Plants. Amsterdam (NL): Elsevier. p 249-269. https://doi.org/10.1016/B9780 -12-384905-2.00008-X

Datnoff LE, Snyder GH, Korndörfer GH. 2001. Silicon in Agriculture Volume 8. 1st Edition. Amsterdam (NL): Elsevier B.V.

Epstein E. 1999. Silicon. Annual Review of Plant Physiology and Plant Molecular Biology. 50: 661-664. https://doi.org/10.1146/annurev.arplant.5 0.1 .641

Fevi MP, Suedy SWA, Sri D. 2017. Pengaruh pupuk nanosilika terhadap jumlah stomata, kandungan klorofil dan pertumbuhan padi hitam (Oryza sativa L. cv. japonica). Buletin Anatomi dan Fisiologi. 2 (1). https://doi.org/10.14710/baf.2.1.2017.72-79

Hadi U. 2013. Pengaruh tras dan pupuk fosfor terhadap pertumbuhan dan produksi padi gogo serta perubahan sifat kimia pada latosol gunung sindur. Bogor (ID): Fakultas Pertanian Institut Pertanian Bogor.

Haynes RJ, Belyaeva ON, Kingston G. 2013. Evaluation of industrial wastes as sources as fertilizing silicon using chemical extractions and plant uptake. Journal of Plant Nutrition and Soil Science. 176(2): 238-248. https://doi.org/10.1002/ jpln.201200372

Haynes RJ. 2014. A contemporary overview of silicon availability in agricultural soils. Journal of Plant Nutrition and Soil Science. 177(6): 831-844. https: //doi.org/10.1002/jpln.201400202

Husnain. 2011. Sumber Hara Silika Untuk Pertanian. Warta Penelitian dan Pengembangan Pertanian. 33(3): 12-13.

Jafari $H$, Madani $H$, Dastan $S$, Malidarreh AG, Mohammadi B. 2013. Effect of nitrogen and silicon fertilizer on rice growth in two irrigation regimes. International Journal of Agronomy and Plant Production. 4 (S): 3756-3761.

Liang YC, Nikolic M, Belanger R, Gong $\mathrm{H}$, Song A. 2015. Silicon in Agriculture: From Theory to Practice. Amsterdam (NL): Springer. https://doi.org /10.1007/978-94-017-9978-2

Lima CC. 2011. Disponibilidade de fósforo para a canade-açúcar em solo tratado com compostos orgânicos ricosem silício. Revista Brasileira de Engenharia Agrícola e Ambiental. 15(2): 1222-1227. https://doi.org/10.1590/S1415-436620 11001200002

Malav JK, Ramani VP, Sajid M. 2016. Effect of nitrogen and silicon fertilizer on growth, yield and yield attributes of rice (Oryza sativa L.) under lowland conditions. The Ecoscan 10(1\&2): 213-216. 
Marxen A, Klotzbucher T, Jahn R, Kaiser K, Nguyen VS, Schmidt A, Schadler M, Vetterlein D. 2016. Interaction between silicon cycling and straw decomposition in a silicon deficient rice production system. Plant and Soil. 398: 153-163. https://doi .org/10.1007/s11104-015-2645-8

Meena VD, Dotaniya ML, Vassanda C, Rajendiran S, Ajay, Kundu S, Subba Rao A. 2014. A case for silicon fertilization to improve crop yields in tropical soils. Proceedings of the National Academy of Sciences, India Section B: Biological Science. 84(3): 505-518. https://doi.org/10.1007/s40011-01 3-0270-y

Nawaz K, Chaudhary R, Sarwar A, Ahmad B, Gul A, Hano C, Abbasi H, Anjum S. 2021. Melatonin as master regulator in plant growth, development and stress alleviator for sustainable agricultural production current status and future perspectives. Sustainability 13(294): 1-25. https://doi.org/10.339 0/su13010294

Ningsih EP, Irfan DP, Diah R, Retno PS. 2012. Laju fotosintesis dan kandugnan klorofil kedelai pada media tanah masam dengan pemberian garam aluminium. AGROTROP: Journal on Agriculture Science 2(1): 17-24.

Nugroho B. 2009. Peningkatan produksi padi gogo dengan aplikasi silikat dan fosfat serta inokulasi fungi mikoriza arbuskular pada ultisol. [Disertasi]. Bogor (ID): Institut Pertanian Bogor.

Paye SW. 2016. Silicon fertilization in rice: establishment of critical silicon level and its impact on availability of nutrients in soils of Louisiana. [Thesis]. Lousiana (USA): Louisiana State University.

Pulz AL, Crusciol CAC, Lemos LB, Soratto R P. 2008. Influência de silicato e calcário na nutrição, produtividade e qualidade de batata sob deficiência hídrica. Revista Brasileira de Ciênciado Solo. 32(4): 1651-1659. https://doi.org/10.1590/S0100-068320 08000400030

Putri FM, Suedy SWA, Darmanti S. 2017. Pengaruh pupuk nanosilika terhadap jumlah stomata, kandungan klorofil dan pertumbuhan padi hitam. Buletin Anatomi dan Fisiologi. 2(1): 72-79. https: //doi.org/10.14710/baf.2.1.2017.72-79

Rao AN, Wani SP, Ramesha MS, Ladha JK. 2017. Rice production systems. Cham (CH): Springer International Publishing. p 185-205. https://doi.org /10.1007/978-3-319-47516-5_8

Raven JA. 1983. The transport and function of silicon in plants. Biological Reviews. 58(2): 179-207. https: //doi.org/10.1111/j.1469-185X.1983.tb00385.x

Rogalla H. Romheld V. Role of leaf apoplast in siliconmediated manganese tolerance of Cucumis sativus
L. 2002. Plant Cell and Environment. 25(4): 549-555. https://doi.org/10.1046/j.1365-3040.2002. 00835.x

Sakr N. 2016. The role of silicon (Si) in increasing plant resistance against fungal diseases. Hellenic Plant Protection Journal. 9(1): 1-15. https://doi.org/10.15 15/hppj-2016-0001

Savant NK, Korndorfer GH, Datnoff LE, Snyder. 1999. Silicon nutrition and sugarcane production: A review. Journal of Plant Nutrition. 22(12): 1853-1903. https://doi.org/10.1080/019041699093 65761

Shuhei M. Kenichi, K. Yuka, S, Ho A. 2009. Uptake of applied silica by rice plants in relation to level of nitrogen application. Bulletin of Yamagata University-Agricultural Science. 15(4): 309-314.

Summer ME, Ferina MPW. 1986. Phosphorus interaction with other nutrients and lime in field cropping systems. Advances in Soil Science. 5: 201-236. https://doi.org/10.1007/978-1-4613-8660 5_5

Szulc W, Rutkowska B, Hoch M, Spychaj FE, Murawska B. 2015. Exchangeable silicon content of soil in a long-term fertilization experiment. Plant Soil and Environment. 61(10): 458-461. https://doi.org /10.17221/438/2015-PSE

Tubaña BS, Heckman JR. 2015. Silicon in Soil and Plants Diseases. Switzerland $(\mathrm{CH})$ : Springer International Publishing Switzerland. https://doi.org /10.1007/978-3-319-22930-0_2

Utomo H. 2011. Pengaruh Kaptan, tras, dan pupuk fosfor terhadap kedelai varietas orba pada podsolik Jasinga. [Skripsi]. Bogor (ID): Institut Pertanian Bogor.

Van Bockhaven J, De Vleesschauwer D, Hofte M. 2013. Towards establishing broad spectrum disease resistance in plants: silicon leads the way. Journal of Experimental Botany. 64(5): 1281-1293. https://doi.org/10.1093/jxb/ers329

Wallace A. 1993. Participation of silicon in cation-anion balance as possible mechanism for aluminum and iron tolerance in some gramineae. Journal of Plant Nutrition. 16(4): 547-553. https://doi.org/10.1080/0 1904169309364555

Zellner W, Frantz J, Leisner S. 2011. Silicon delays Tobacco ringspot virus systemic symptoms in Nicotiana tabacum. Journalof Plant Physiology. 168(15): 1866-1869. https://doi.org/10.1016/j.jplph .2011 .04 .002

Zulputra, Wawan, Nevia. 2014. Respon padi gogo (Oryza sativa L.) terhadap pemberian silikat dan pupuk fosfat pada tanah ultisol. Jurnal. Agroteknologi. 4(2): 1-10. 